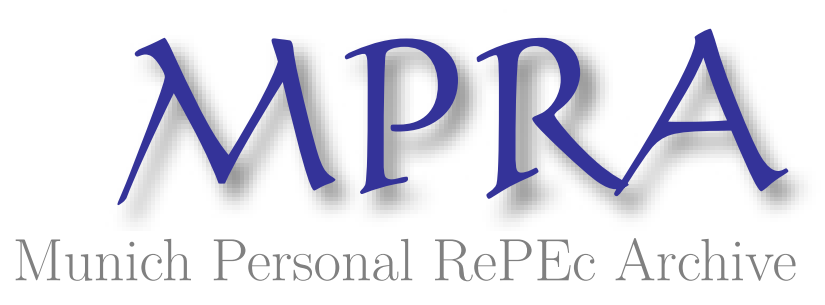

\title{
Historical Examination of the Golden Age of Full Employment in Western Europe
}

Singh, Ajt

2008

Online at https://mpra.ub.uni-muenchen.de/24304/

MPRA Paper No. 24304, posted 29 Aug 2010 09:16 UTC 


\section{Chapter 3: Historical Examination of the Golden Age of Full Employment in Western Europe ${ }^{1}$}

\section{Ajit Singh, University of Cambridge}

\section{Introduction}

The main purpose of this paper is to review the lessons of the "Golden Age" with respect to establishing and maintaining full employment in advanced countries.

The golden age, generally regarded as spanning 1950-1973 was a unique period in West European economic history. During this period of about 25 years following the end of the Second World War, the West European economies expanded at the unprecedented rate of 5 per cent per annum, nearly twice the rate recorded during any previous phase, and more than twice the average rate of growth from 1820 to 1950.

Significantly, this strong growth record was associated with an equally strong record of employment. (This is long before the days of jobless growth.) Leading West European economies experienced a quarter century of virtual full employment. Indeed, Germany and France not only enjoyed full employment but were characterised by what could be called overfull employment in the sense that they were able to offer employment to a sizeable numbers of migrant workers in addition to the domestic labour force. Foreign workers in these countries constituted nearly ten per cent of the labour force in the 1960s.

Indeed it was claimed that in the post-World War II capitalist economies, the business cycle had been overcome. This was attributed to the fact that contrary to previous experience, even in downturns the economic growth rate was still positive. As the golden age continued over an extended period it came to be regarded as the new norm for capitalist economies rather than the exception. Frenkel and Johnson (1976), in a well-known book of the period, on the monetary approach to the balance of payments, observed "More fundamentally, the assumption of normally full employment reflects the passage of time and the accumulation of experience of reasonably full employment as the historical norm rather than the historical rarity that Keynes's theory and the left-wing Keynesian mythology made it out to be" (p. 25).

As the subsequent events showed, however, the golden age was an aberration certainly in the statistical sense (see further next section) but, more importantly, it is argued here that it was also so in economic terms. It represented a model of economic development for European countries, which differed both from the pre-war and postgolden age models. It was a model based on cooperation between workers, employers and the government and its workings represented an institutional consensus on real wages, profits and welfare benefits. The questions to be asked are: how the model came to be established and why it resulted in such successful outcomes in continental Europe during the golden age.

\footnotetext{
${ }^{1}$ This paper is based on Singh (forthcoming). I am grateful to Rolph Van der Hoeven for permission to use material from that article in the present paper.
} 
Another key question is what accounted for the relatively poor US performance in this period compared with that of European countries. This question becomes more significant since during the last decade (1995-2005), the US has performed much better than Western Europe. How is this great reversal to be explained?

Some simple statistics provide a dramatic illustration of the contrasting employment records of the US and Europe in the golden age and subsequently. During the decade prior to the end of the golden age (1963-1973), the German unemployment rate averaged at a little over one per cent per annum, compared with an average of more than eight per cent for the recent decade 1994-2003. The source of these data is Table 3 in Section 2).

In contrast, in the US there has been no long-term trend increase or decrease in the rate of unemployment during the last 50 years - the trend line has been flat. Contrary to the experience of the Golden Age, the average US long-term unemployment is lower than that of France and Germany in the recent period.

Similarly since 1995, the US growth rate has been much faster than that of either France or Germany, leading to concern that Europe is falling behind. Instead of convergence towards the higher US level of GDP per capita that was being achieved by European countries during the golden age, there has since been divergence, which appears to be increasing.

Leading European political scientists Alberto Alesina and Francesco Giavazzi (2006) have recently written a provocative analysis suggesting that, unless the European countries reform their economies along the US lines they will fall even further behind. In their view, the European overgenerous welfare state, labour market rigidities, higher taxes, lower working hours, excessive influence of trade unions, restrictions on immigration and the lack of competition and entrepreneurship are all areas requiring concerted reform in continental Europe. Needless to say, these are controversial views that do not command universal support. ${ }^{2}$

It is important to note that the above strictures do not apply to all parts of Europe. The UK is regarded as a notable exception and an example to others in Europe. Mrs Thatcher's onslaught on the trade unions and the Blair labour government's pledge not to reverse these initiatives are noted with approval by Alesina and Giavazzi (2006). It is also accepted by these liberal thinkers that the Scandinavian countries have also performed as well as the US if not better but they argue that this experience is unique to this region due to its being rooted in its long social democratic history and therefore provides few lessons for other countries.

Oliver Blanchard (2004), provides a strong conceptual challenge to the above thesis, arguing that Europeans prefer to enjoy the fruits of economic progress in terms of increased leisure time and lengthier holidays. He suggests that productivity in France in terms of GDP per person hour is now on a par with the US. This, however, is denied by Phelps (REF.; the recent Nobel prize-winning economist), and Zoega (2004) who use a different set of data that suggests that France has fallen further

\footnotetext{
${ }^{2}$ For critical reviews of Alberto Alesina and Francesco Giavazzi's theses see Carlin 2007, Cohen 2007, Prescott 2007.
} 
behind the US even in terms of productivity per person hour. Indeed, the two authors suggest that France and Germany have fallen behind the US on all relevant measures of economic performance. (Phelps and Zoega Table 3, page 10.)

Essentially, Phelps and Zoega (op. cit.) suggest that what is at fault is the European lack of dynamism in terms of entrepreneurship. One measure of the latter is the average value of the stock market index in each country. Not everyone will however be convinced by the accuracy, even relevance of this measure. The US ranks ahead of Europe on every one of the specific entrepreneurship measures introduced by Phelps and Zoega (op. cit.).

It is arguable that the root of these controversies lies in the experience of different economies in the golden age. During this period, the French, the Germans and the Japanese economies performed strongly, while the US and the British did relatively poorly in comparative international terms, though well in relation to their own longterm records.

The question is what policies (and other factors) accounted for these outcomes?

The paper is organized as follows. After describing briefly the economic records of the Golden Age in Europe and U.S. in a long term historical perspective, the paper first asks, how did the golden age model come into being and to prevail? Second, how did the model work? Third, why did it fail? Fourth, should it or can it be revived? What are the lessons of the golden age for the present? Is the situation so different that any lessons are irrelevant?

\section{The Golden Age in Long-term Historical Perspective}

To complete the statistical picture introduced partially in Section 1 with some data on unemployment, Tables 1-3 give the basic information on the comparative record of the golden age phase of development. The period stands out unequivocally as one of the fastest growth of productivity, GDP, capital stock and the volume of exports for Western Europe ${ }^{3}$. The story for the US is somewhat different in that, although the US recorded its fastest growth of productivity in the golden age, the highest GDP growth rate was registered in the period 1820-1870, $4.2 \%$ v $3.1 \%$ during the golden age.

\footnotetext{
${ }^{3}$ In addition to the works cited in this Section, see also Crafts (1997), Eichengreen (1996).
} 
Table_1. Growth characteristics of different phases: 1820-1996

12 West European Economies* (Arithmetic average of figures for the individual countries) (Annual average compound growth rates)

\begin{tabular}{lllllll} 
Phases & GDP & & $\begin{array}{l}\text { GDP per } \\
\text { head of } \\
\text { population }\end{array}$ & & $\begin{array}{l}\text { Tangible } \\
\text { reproducible } \\
\text { non-residential } \\
\text { fixed capital } \\
\text { stock }\end{array}$ & $\begin{array}{l}\text { Volume of } \\
\text { Exports }\end{array}$ \\
& W. & U.S. & W. Europe & U.S. & W. Europe & W. Europe \\
& Europe & & & & & \\
\hline I $(1820-70)$ & 1.7 & 4.2 & 0.9 & 1.3 & (N.A) & 4.4 \\
II $(1870-1913)$ & 2.2 & 3.9 & 1.3 & 1.8 & 2.9 & 3.2 \\
III $(1913-50)$ & 1.8 & 2.8 & 1.2 & 1.6 & 1.7 & 0.7 \\
IV $(1950-73)$ & 4.6 & 3.9 & 3.8 & 2.4 & 5.5 & 8.6 \\
V $(1973-96)$ & 1.9 & 2.5 & 1.7 & 1.5 & 3.91 & 4.5 \\
\hline
\end{tabular}

Sources: G1xn, Hughes, Lipietz and Singh (1990) Maddison (1997)

* The 12 West European Countries are: Austria, Belgium, Denmark, Finland, France, Germany, Italy, Netherlands, Norway, Sweden, Switzerland, UK.

$11973-89$

Table 2 suggests, in a long-term historical perspective, how low the golden age unemployment was relative to that in other periods. Table 3 gives standardized unemployment rates for industrial countries for various periods from 1964 to 2003.

However, on one dimension the golden age does not do so well; the average rate of inflation was much greater than that in the previous phases. This was largely because in the Golden Age, there were no long-term depressions or crises, which recorded sizeable falls in prices. Nevertheless, the golden age was an era of relative price stability compared with the post-golden age period. Further, 20 years of moderate inflation did not degenerate into hyperinflation. 
Table 2: Unemployment and Inflation in Western Europe during Different Phases

12 West European Countries

(Arithmetic average of figures for individual countries)

\begin{tabular}{ll}
\hline \multicolumn{1}{c}{$\begin{array}{c}\text { Average } \\
\text { Phases }\end{array}$} & $\begin{array}{l}\text { Average annual rise } \\
\text { in consumer prices } \\
\text { (aercentage of labour force) }\end{array}$ \\
\hline
\end{tabular}

$\begin{array}{llll}\text { I } & 1820-70 & \text { (n.). } & 0.7^{1} \\ & 1870-1913 & 4.5 & 0.2 \\ \text { II } & 1920-38 & 7.3 & -0.1 \\ \text { III } & 1950-73 & 2.4 & 4.2 \\ \text { IV } & 1973-83 & 4.9 & 9.4 \\ \text { V } & 1983-95 & 7.5 & 3.8\end{array}$

Source: Maddison (1997)

1 France, Germany, Sweden, and USA only

The robust growth of capital stock in Table 1 is confirmed by the inter-country figures for investment as a proportion of GDP. Data indicates that the rate of investment as a proportion of GDP rose in leading industrial countries during the golden age: in France gross fixed investment as a share of GDP excluding housing investment, rose from $12 \%$ in the 1920 s and 1930 s to $14 \%$ in the 1950 s and $17 \%$ in the $1960 \mathrm{~s}$; the corresponding figures for Germany increased from $11 \%$ to $17 \%$ in the 1950 s and $18 \%$ in 1960s. In the U.K. gross fixed non-housing investment as a proportion of GDP rose from $6 \%$ in 1920 s and 1930 s to $12 \%$ in the 1950 s and $15 \%$ in the 1960 sEichengreen (2007).

The volume of exports also rose during the Golden Age at almost twice the rate in the previous historical phases. This was, however, in part due to the fact that there had been widespread protectionism during the 1930s in European countries and the U.S. so that the initial starting point for the volume of international trade before World War II was quite low. 


\section{Table 3: Standar dized Unemployment Rate, 1964-2003 (Avertge ammul petcentage changes)}

\begin{tabular}{lrrr}
\hline Counity & $1964-1973$ & $1984-1993$ & $1994-2003$ \\
\hline United States & 4.5 & 6.5 & 5.2 \\
Japian & 1.2 & 2.5 & 4.2 \\
Gemmany & 1.1 & 6.5 & 8.4 \\
United Kingdom & 3.0 & 9.2 & 6.7 \\
Total of G7countries & 3.1 & 6.7 & 6.5 \\
Total of EU 15 & 2.7 & 9.5 & 9.3 \\
Total of OECD & 3.0 & 6.9 & 6.6 \\
\end{tabular}

Source: OECD, Historical Statistice; IMF

\section{Evolution of the Golden Age}

As Matthews and Bowen (1988) has suggested, although there are many accounts of the fall of the golden age, there are very few concerning its rise. No one predicted the post World War-II golden age boom. Based on the experience of the post First World War period which followed the end of World War-I the general expectation of economists was that it would be difficult to maintain the level and growth of aggregate demand to sustain full employment after World War-II. So what accounted for this surprise turnaround represented by the golden age? An immediate response to this question is to say that there was widespread destruction during the war and the subsequent faster growth was due to reconstruction activities ${ }^{2}$. However, evidence does not support this interpretation. The West European economies recovered very quickly after the war. In countries other than Germany, the pre-war (1938) peak production level was once more reached in 1947. The German pre-war peak was reached again in 1948. This is not surprising as the strategic bombing surveys revealed that only 10 per cent of German industrial capacity was destroyed by allied bombing. Supply reference?

A second theory is that of "catch-up": a big gap had opened up between Europe and the USA in terms of productivity levels. At the beginning of World War 1, US productivity was 25 per cent higher than that of Europe. The gap had narrowed somewhat during the 1930s as a result of the depth of the depression in the USA. However, during the war, not surprisingly the US economy did significantly better 
than the European economy not least because it had not been subject to the same level of destruction as the latter group of economies, the transatlantic productivity gap had increased (see Table 4). This led to considerable room for "catch-up" by European economies. There are, however, two points worth noting in relation to this issue. The first is that catch-up is not by any means automatic, as the experience following World War 1 showed. In order for catch-up or convergence to occur, there need to be in place the required institutions as well as capabilities in the reference countries. Secondly, regression analysis shows that "catch-up" at best accounts for about 50 per cent of the inter-country variation in growth rate. Eichengreen (1996) and Crafts and Toniolo (1996).

Table- 4

Gross domestic product per capita and per hour, 1913-2003

191319291938195019732003

\section{GDP per capita as percentage of U.S. levels}

\begin{tabular}{lccccccc} 
France & \multicolumn{2}{c}{66} & 68 & 73 & 55 & 79 & 73 \\
Germany & 69 & 59 & 82 & 41 & 72 & 64 & \\
Italy & 48 & 45 & 54 & 37 & 64 & 66 & \\
United Kingdom & 93 & 80 & 102 & 73 & 72 & 72 & \\
$\quad$ EU-15 average & 57 & 55 & 66 & 47 & 65 & 72 &
\end{tabular}

GDP per hour as percentage of U.S. levels

\begin{tabular}{|c|c|c|c|c|c|c|}
\hline France & 5 & NA & $\mathrm{N}$ & 46 & 7 & 111 \\
\hline Germany $^{\mathrm{a}}$ & 59 & NA & NA & 32 & 79 & 98 \\
\hline Italy & 42 & NA & NA & 35 & 78 & 100 \\
\hline United Kingdom & 84 & NA & NA & 63 & 60 & 83 \\
\hline EU-15 average & 61 & NA & NA & 44 & 71 & 94 \\
\hline
\end{tabular}

Source: reproduced from Eichengreen (2007).

${ }^{a}$ West Germany for 1950 and 1973.

${ }^{\mathrm{b}}$ The following countries are excluded from the EU-15 average due to lack of data. 1913 and 1950: Greece, Ireland, and Spain; 1973: Greece, Luxembourg, and Portugal; 2003: Belgium and Luxembourg.

Another seemingly plausible theory, which does not fit the facts is that the Golden Age boom was a product of Keynesian demand management policies. In an important paper, Matthews (1968) pointed out that there was no deficit spending in post World War II Europe. Countries, generally speaking, enjoyed fiscal surpluses rather than deficits to sustain demand. The Golden Age boom was a creation of the private sector. Madison (2001) provides a somewhat different interpretation of the Golden Age boom. He suggests that it was fundamentally Keynesian phenomena in that the private sector knew that the governments will not let a deficiency of aggregate demand to occur and, therefore, corporations could invest with much less risk than would otherwise be the case. 
Although, there are some mono-causal theories of the rise of the Golden Age, there exist two leading comprehensive accounts of the rise of the golden age, which have some common ground, whilst manifesting differences. ${ }^{4}$ Glyn, Hughes, Lipietz and Singh (GLHS) 1990, in a left wing-Keynesian analysis, argue that the golden age was made possible by the coming together of a number of factors. They suggest that the Golden Age economic model involved catch-up, an institutional consensus on wages prices and profits and multi-lateral economic organisations to guide international trade and capital flows. This novel institutional set-up was partly a matter of design and partly it arose from conjunctural events. One of the most important of the latter was the post World War II situation in Europe involving confrontation between two rival systems of economics and political organisation: the Soviet system characterized by national planning and Communist Party dictatorship and the US system of a liberal market economy and a liberal democracy.

At the end of World War II the Soviet Union had a great deal going for it. It had just won a war against a super industrial power, Germany; the crimes of the Stalin period had not yet been made public. There were sizeable communist parties in Italy and France with a distinguished record of résistance to fascism. In these circumstances despite the split between communist and catholic trade unions the west European ruling circles were obliged to make genuine concessions to the workers. This is how productivity wage bargaining came to be accepted with the fundamental idea that the workers had a right to equitable sharing of the fruits of economic progress. This brought into being the social market economy with representation by workers on supervisory boards of corporations. Germany is the best examples of this evolutionsee further GHLS (1990) and Eichengreen (2007) and the literature referred to in these contributions.

Thus, GHLS (1990) stressed the simultaneous operation of a host of factors to explain the Golden Age boom. They proposed the following four-fold classification scheme to explain the high rates of investment sustained over a 25 year period:-

a) Macro-economic pattern - macro economic relations which ensure the perpetuation of the growth path. This concentrates on the relationships between profits, investments, wages and productivity.

b) The operation of the system of production, techniques of production and organisation of work.

c) Institutional and behavioural framework which considers the compatibility between individual action and macro-economic pattern - wage setting and pricing institutions, welfare state, credit and fiscal policies.

d) International regulation.

GHLS (1990) stress that it is not enough to have the necessary requirements met in each of the four spheres, but there also needs to be an overall coherence between the spheres. The high growth path of the Golden Age which resulted from satisfactory

\footnotetext{
${ }^{4}$ For mono-causal accounts, see Kalidor, Kindelberger, Beckermann [to supply years for the reference]
} 
performance in each sphere as well as being compatible between them was unstable. The institutional base on which it was constructed did not have any provision for institutional renewal, or for the supply of new institutions to cope with the changing circumstances.

An institutional analysis similar to that of GHLS (1990) is a recent one by Eichengreen (2007). His basic argument is couched in dynamic game theory terms. The theoretical basis for his analysis lies in cooperative dynamic game theory. (See Van der Ploeg and Grout) [X] This, he suggests was made possible by institutional solutions which were adopted by European countries to remedy (a) co-ordination problems both internally and externally and (b) time inconsistency problems.

Following Van der Ploeg and Grout, Eichengreen suggests that welfare is maximized when workers moderate their wage claims in order to make profits available to enterprise. Capitalists restrain dividend pay-outs in order to re-invest. Investment stimulates growth raising the future incomes of both capitalists and workers. In the co-operative equilibrium in which both workers and capitalists exercise restraint the cost of foregoing current consumption are dominated by benefits of future increase in incomes accruing to both.

Where Eichengreen (2007) difers from GHLS (1990) is his suggestion that the most important motivation for the new post World War II institutional arrangements was the experience of the Great Depression of the 1930s, which exposed widespread coordination failures of the market economy. He suggests that corporatist solutions were a part of the European tradition since at least Bismark. His analysis differs not only from GHLS (op. cit.) who, as seen above, emphasize the post World War II European conjuncture in the rise of new institutions but also from that of Olsen (1996). Olsen's argument, which has been widely influential, is that the destruction of the old institutions and vested interests connected with them leads to fast economic growth. On the contrary, Eichengreen's (2007) analysis emphasizes the continuity of the old and new corporatist institutions rather than the demise of the old to explain the rise of Golden Age.

\section{The Workings of the Golden Age}

\subsection{Macro-economic Pattern}

In terms of the GHLS (1990) four-fold classification scheme, the Golden Age was characterised in relation to the Macro-economic Pattern by the following two relationships:

\subsubsection{Rapid and parallel growth of capital stock and productivity}

- Parallel growth of real wages and productivity.

These two relations ensure that the share of profits and wages in national income and the rate of profit more or less stay constant. 
- $\quad$ Further, that the rate of growth of consumption and production are in step with each other so that at the macro-economic level, there is neither under consumption nor inflation.

GHLS (op. cit.) analysis suggested that investment was the most important determinant of productivity growth. On the basis of the data for the last 100 years, it was found that on average $1 \%$ growth of capital stock per worker employed resulted in increased productivity growth of $0.75 \%$ per annum.

\subsubsection{System of production and of work}

The system of production, which prevails in the Golden Age enabled convergence to occur between the European and the US levels of productivity. There was a great deal of scope for such catch-up, as suggested in Table 4. With the US help to European countries to adopt American work practices (Fordism, scientific management), and new technology through multi-national investment by American corporations in Europe, there were fast increases in European productivity of capital as well as labour. Either for altruistic or for strategic reasons in relation to the US rivalry with the Soviet Union, the US encouraged such technology transfer to western Europe and Japan.

\subsubsection{Institutional and behavioural framework}

It involved the attainment of an institutional consensus between labour, employers and the government on wage moderation by labour, high investment by employers, with the government ensuring that the fruits of economic progress were equitably shared.

\subsection{International Co-ordination and regulation}

Unlike the post World War I economy, the international economy following World War II was carefully regulated under US hegemony. The US and the UK prepared during the War for the post- war shape of things to come and planned to set up a number of international institutions to govern the world economy. These included:

1. An international organisation for the maintenance of exchange stability and to deal with balance of payments problems.

2. An international organisation to deal with long-term international investment.

3. An international agreement on primary-commodity price control.

4. International measures for the reduction of trade barriers.

5. The international organisation of relief and reconstruction, and

6. International measures to maintain full employment.

In the event, not all these institutions could be set up but a sufficient number were established to provide a stable framework for the international economy after World War-II. The US activism in encouraging the formation of European Union and the decision to provide Marshall Plan aid to Europe further strengthened the liberal 
economic framework of the international economy and played a decisive role in the rise of the Golden Age. As Spero (1977) noted: "In the short term it (the United States), dealt with its own huge balance-of-trade surplus and the European and Japanese deficits by foreign aid and military expenditures. In addition, the United States abandoned the Bretton Woods goal of convertibility and encouraged European and Japanese trade protectionism and discrimination against the dollar. For example, the United States absorbed large volumes of Japanese exports while accepting Japanese restrictions against American exports... To encourage long-term adjustment, the United States promoted European and Japanese trade competitiveness" (P.37).

During the Golden Age, a positive feedback mechanism was at work. High investment led to high productivity growth, which, in turn, led to high real wages and consumption, to high demand and high investment. The Golden Age growth path benefited from this positive feedback, which also strengthened its corporatist institutional underpinnings. However, in the absence of a mechanism for institutional renewal and of creating new institutions to meet economic shocks and other challenges, the growth path was unstable and could be blown off course by difficulties in any of the four spheres in the GHLS (1990) scheme.

In Eichengreen's (2007) analysis, the workings of the Golden Age involved continuing consultations between Unions, employers and the government on central economic parameters in order to coordinate economic activity. The government tried to ensure that both labour and capital were engaged in a whole range of overlapping bargains so that neither side felt able to reneg from their obligations.

\section{Fall of the Golden Age}

Unlike the rise of the Golden Age, there are many more theories and hypotheses concerning its fall. The latter have been reviewed by GHLS (1990) who systematically compared alternate explanations. A leading cause of the failure of Golden Age was the long-term trend decline in the rate of growth of productivity, beginning in the late 1960s. In addition, there was increased militancy among workers after 20 years of full employment. This was reflected in the May 1968 events in France and the increased strike activity in European countries. Workers abandoned wage moderation, leading to a breakdown of the basic Golden Age consensus over profits and wages. This also resulted in a profit squeeze and lower investment by employers. Further, the international economic system suffered a huge shock with the end of the gold convertibility of the US Dollar and the virtual demise of the Bretton Wood system. This also could be expected to lower the propensity to invest.

To sum up, analysis and evidence point to three proximate economic causes of the fall of the Golden Age: (a) Productivity slow down due to exogenous factors as well as reduced scope for catch-up as the European economies developed; (b) the un-ravelling of the Golden Age consensus over wages and profits and (c) the breakdown or at least a big question mark over the international framework for trade and capital flows with the end of the Bretton Woods system. The latter can be ascribed in part to the success of the Golden Age itself and that of the US policies to strengthen the economies of its allies in Western Europe and Japan. This resulted in varied evolution of competitive capacities of the leading industrial economies. Thus, over the two decades 1950 to 1970, the U.S. share of world exports of manufactures declined from 27.3 per cent to 
18.5 per cent; over the same period, the West German share showed a matching improvement form 7.3 per cent in 1950 to 19.8 per cent in 1970. Similarly, during these twenty years, the U.K.'s share of world manufacturing exports declined from 25.5 per cent to 10.8 per cent whilst that of Japan improved from 3.4 per cent to 11.7 per cent. The relatively poor trading performance of the reserve currency countries, namely the US and the UK, contributed to the difficulties of the Bretton Woods system.

In relation to the breakdown of the consensus on wages and profits, Kalecki (1943) in a famous paper had suggested that full employment capitalism was not a viable proposition because employers need to have the power of the sack to discipline workers. In fact, what actually happened in the demise of the Golden Age were the excessive wage demands of workers rather than the capitalists prevailing on the government to keep a reserve army of the un-employed.

In accounting for the fall of the Golden Age, Eichengreen (2007) gives the main cause to be the near exhaustion of catch-up possibilities and, therefore, the slow down in productivity growth due to this reason as well as due to exogenous factors. This, he suggests made it less attractive for workers to have an agreement with employers over wages and profits. GHLS (1990) provide a more nuanced explanation for the fall of the Golden Age. In their view, the internal and external factors interacted to the detriment of the Golden Age consensus. Economists' high hopes from floating exchange rates, which followed the end of the Bretton Woods system proved to be illusory. Most advanced countries adopted dirty floating in order to protect their economies from un-desired currency movements. The net result was that the international system could no longer provide balance of payments equilibria at sufficiently high growth rate to ensure full employment in the participating countries.

GHLS (op. cit.) suggest that even without the 1973 oil price shock, the Golden Age system would have come to an end because of the difficulties outlined in the above analysis.

Between 1973-78 the industrial countries attempted to deal with these problems by following Keynesian demand management policies. This led to some improvement in overall economic performance between 1974-1978, but this was not enough to create a new Golden Age consensus in the changed circumstances. By the time of the second oil shock, the response of the US Federal Reserve led by Paul Volcker was to abandon any pretence of compensating for the deflationary effects of the fall in world aggregate demand arising from the lower propensity to consume of the oil producing nations. The so-called 'Volcker shock' raised real US and international interest rates (LIBOR) from $0.5 \%$ to $7 \%$ by means of a highly restrictive monetary policy. This policy was emulated by other countries particularly the UK, leading in turn to what may be called competitive deflation among main industrial countries.

Thus, out of the 'stagflation' (high inflation and low growth), the failures of the normal demand management policies and the breakdown of the Golden Age system in leading advanced countries, the US and the UK, under Reagen and Thetcher respectively, inaugurated the new post Golden Age economic model of liberalisation 
and globalization. This model accorded primary attention to the control of inflation rather than to achieve full employment. Through privatization and de-regulation, this model involved a far greater role for un-impeded market forces than the Golden Age model. The mass un-employment, which arose from these restrictive economic policies in advanced countries in the late 1970s and early 1980s, emasculated organised labour and raised the power of capital. The question is whether this new model is capable of restoring full employment for all those who wished to be employed (i.e. there is no involuntary un-employment) together hopefully with rising real wages. There are serious doubts on this score.

\section{Lessons from the Golden Age and the Evolution of the Market Supremacy Model}

The foregoing analytical narrative raises three important questions in the context of this paper. First, what lessons can be drawn from the rise and fall of the Golden Age for achieving and maintaining full employment in advanced countries. Secondly, how has the post-Golden Age model evolved since the adoption of restrictive monetarist policies in the US in the late 1970s. Thirdly, how successful and how efficient is the post Golden Age model. We will take up these questions in turn.

The main lessons from the Golden Age may be summarised as follows:-

A co-operative economic regime at the national and international levels, based on appropriate institutions can deliver outstanding economic success, full employment, fast growth of productivity and real wages in the North as well as rapid industrialisation in the South in a positive sum game. ${ }^{5}$

At the national level, the appropriate institutions were those of a social market economy, committed to fast economic growth, full employment and equitable distribution of the fruits of economic progress. At the international level, it required inter alia, institutional arrangements that would permit balance of payments disequilibria between countries to be resolved at high rates of growth of real world demand, as well as national demand and output. It may be noted that the latter arrangements represented a solution to the problem articulated by Keynes in the following famous lines:

The problem of maintaining equilibrium in the balance of payments between countries has never been solved...the failure to solve this problem has been a major cause of impoverishment and social discontent and even of wars and revolutions...to suppose that there exists some smoothly functioning automatic mechanism of adjustment which preserves equilibrium if only we trust to matters of laissez faire is a doctrinaire delusion which disregards the lessons of historical experience without having behind it the support of sound theory.

\footnotetext{
${ }^{5}$ This question is discussed in Singh (2007) with particular reference to rapid industrial development in India and China.
} 
The essential point here is that the balance of payments will always balance, subject to recording errors. An important economic policy issue is at what rate of economic growth would this balance occur.

In step with the national institutions, the international institutions were also committed to fast growth and full employment. Thus, for example, in the very first clause of the Preamble to the General Agreement on Tariffs and Trade (GATT), it is stated that: "the contracting parties declared themselves as: Recognizing that their relations in the field of trade and economic endeavour should be conducted with a view to raising standards of living, ensuring full employment and a large and steadily growing volume of real income and effective demand, developing the full uses of the resources of the world...."

An important lesson of the Golden Age was that there should be coherence between internal and external regulation. Also required is continual institutional change and renewal with changing circumstances. This did not happen in the Golden Age, which greatly contributed to its demise.

As explained above, the Golden Age co-operative model was abandoned after its failure in the 1970s. Under Thatcher and Reagan, a model of non-cooperation within countries and minimum cooperation inter-nationally, together with market supremacy, both internally and externally, was adopted in its place. This is the model of liberalisation and globalisation.

\subsection{Contours of the Market Supremacy Model}

As we are to assess the success and efficiency of the post-Golden Age model, it is important to define it more precisely. Globalization means all things to all people, but for analytical clarity the emphasis here is on free movement of capital, goods and services between countries, but excluding free flows of labour. This is despite the fact that the efficiency advantages of the latter are likely to be greater than, for example, that of free movement of goods or capital. This is for the simple reason that in the real world the price of labour is much more distorted compared with distortions in the price of capital or of goods (Rodrik 2001). Advanced countries as well as the international financial institutions (IFIs), which are the principal architects of globalization, suggest fully-flexible labour markets within each country as another essential component of globalization under current rules.

Globalization has occurred at different speeds in different countries and has often been an uneven but cumulative process. Nevertheless, in most advanced economies, globalization in the above sense of near free trade with very low tariff barriers and almost free capital movements was achieved by the first half of the 1980s and in many DCs by the early to mid-1990s. Multinational corporations are one of the main actors in this globalization drama. A relatively small number of these companies have a disproportionate share in world trade and world production and, together with large financial corporations, are deeply involved in international short- and long-term capital flows. 
It will be instructive to review briefly the experience of the inter-war period in relation to possible future of evolution of economic globalization. The liberal international economic regime of the 1920s that operated between major industrial countries came to an end in the 1930s as a result of the high unemployment associated with the great depression. Thus John Hicks observed: "The main thing which caused so much liberal opinion in England to lose faith in Free Trade was the helplessness of the older liberalism in the face of massive unemployment, and the possibility of using import restriction as an element in an active programme fighting unemployment. One is, of course, obliged to associate this line of thought with the name of Keynes. It was this, almost alone, which led Keynes to abandon his early belief in Free Trade." (Hicks, 1959; quoted in Bhagwati, 1994, p. ???).

Orthodox economists often regard globalization as a technology-driven inexorable process, particularly with respect to financial globalization, partly because of the assumed difficulty of re-regulation. What the experience of the 1930s suggests is that the present globalization of free trade and free capital movements is simply one way of organising the world economy and will only be sustainable if it meets the needs of the people North and South. Re-regulation will take new forms and also use new technology to achieve this.

Thus, while the thesis that liberalization and globalization are entirely technologydriven is far from being convincing, as will be seen below, the ICT revolution nevertheless plays a critical role in the present workings of the world economy. It is central to competitiveness and the economic growth of corporations as well as of countries. It has played a particularly important role in some countries such as US (see below) and India over the last two decades, raising the possibility whether the latter may be able to leapfrog stages of development. ${ }^{6}$

\section{The Success and Efficiency of the Post-Golden Age Model}

The post-Golden Age model of liberalization, globalization and market supremacy has been in operation in advanced countries almost as long as the Golden Age model itself. It is, therefore, in order to compare economic performance under the two regimes. Until 1995 the answer to the question as to which model has performed better among industrial countries was unambiguous. The data indicated a fall in the GDP growth since the Golden Age in almost all the OECD countries. However, since 1995 the situation has changed in one important respect: the US has recorded a trend increase in its long term growth rate of almost one percentage point, from 2.5 percent per annum to 3.5 percent per annum, a colossal achievement for a non catch-up economy operating at the frontiers of new technology. See Jorgensen and others $[\mathrm{X}]$. However, there has been no such improvement for European countries during the post- Golden Age period. West European countries continue to have low growth and high single digit rates of un-employment.

Would one expect the average growth rate in the post-Golden Age period to decline in the normal course of events due for example to deceleration in technical progress. If such a decline is expected for various reasons, poorer growth performance during the

\footnotetext{
${ }^{6}$ For a fuller discussion of this subject, see Dasgupta and Singh (2005-2006)
} 
last two decades may not indicate any inherent inefficiency of the post-Golden Age model of development.

There is, however, no economic reason why growth rate should normally decline in the second period. On the contrary, one should expect the pace of economic growth to accelerate because of

the backlog of the new technology of the Information and Communication Technology (ICT) revolution.

\subsection{The flexibility and intensity of competition in various markets}

Further to (a), the ICT technological innovations have been regarded by economic historians, as being at par with the steam engine and electricity and other similar major technological revolutions of the past two centuries. Freeman (1989); and Freeman and Soete (1999). Comparing the potential impact of ICT to that of electricity, ICT does not only directly assist production in almost all other industries as does electricity, but unlike electricity, the former also creates new products and services such as internet, e.mail, fax and networking. Apart from the effects of new technology, with respect to (b), the product markets, the labour markets and capital markets have all been reformed since the end of the Golden Age. The latter, according to received theory, should also enhance economic performance compared with the Golden Age.

Thus, a priori economic performance should, other things be equal, be better under the post-Golden Age model than under the Golden Age model. The overall slowdown in economic growth, witnessed in European countries in the second period, therefore, suggests serious deficits in the post-Golden Age model. Further, high un-employment in European countries in itself manifestly indicates economic inefficiency. Similarly, in the developing world the record of the countries (e.g. those in Latin America and Africa), which have adopted the market-oriented Washington consensus policies, is generally speaking quite poor in the post-Golden Age period compared with the Golden Age. It is also poor in comparison with that of Asian countries, particularly India and china, which did not follow the Washington consensus policies. Rodrik and Subramanian (2004).

In the post-Golden Age period, there are also other deficits of the current situation, which are being revealed. The first of these is the present turmoil in the world economy. That may yet lead to a 'hard landing' with a worldwide recession, starting in the US. Another pathological symptom, which deserves attention, is the fact that the capital flows in the world economy today are from the poor to the rich countries (e.g. Chinese purchase of US Treasury paper) rather than the other way around. A further anomaly is indicated by the fact that advanced countries which are living beyond their means (e.g. have a current account deficit) such as the US have grown at a faster rate during the last decade than countries like Germany and Japan which live well within their means.

The foregoing analyses suggests that the sub- performance of both rich and poor countries under the post-Golden Age model may be improved by introducing direct coordinating mechanisms from the economic model of the Golden Age. Specifically, 
the use of pay coordination policies, cooperation between leading economic powers to re-balance the world economy through mutually agreed exchange rate changes and rates of economic growth would be helpful in overcoming some of the pathological outcomes referred to above. The highly successful experiences of Netherlands and Ireland with such coordination mechanisms including pay restraint and coordination under government supervision and encouragement, point in the same direction. As Eichengreen (2007) rightly argues that the positive outcomes for employment and economic growth in these countries were achieved not by further liberalization of markets but rather by the implementation of extra market coordination mechanisms. This enabled these countries to have a combination of competition and cooperation, which is superior to a regime of competition alone. See further World Bank (1993) and Stiglitz (1999).

\section{Conclusions}

To conclude, briefly, the Golden Age model is far from being a spent force. Parts of it continue to be relevant to improve economic performance, particularly with respect to employment and un-employment. The post-Golden Age market supremacy model cannot deliver full employment on a sustained basis for the well-known Keynesian reasons. The model needs to be supplemented by the introduction of coordinating mechanisms from the Golden Age in order to ensure full employment with rising real wages in both rich and poor countries. This is entirely compatible with the supply side potentialities of the world economy, which has, among other factors, a backlog of innovations yet to be exploited from a revolutionary new technological paradigm. 


\section{Ref e r e n e s}

Alesina (Alberto) and Giavazzi (Francesco). The Future of Europe: Reform or Decline. (Cambridge Mass and London: MIT Press, 2006.

Bhagwati [to be supplied]

Blanchard, Olivier. 2000. "The Economics of Unemployment." Manuscript, Massachusetts Institute of Technology.

Blanchard, Olivier. 2004. "The Economic Future of Europe." Journal of Economic Perspectives 18: 3-26.

Carlin, W. (2007). Review of Alesina and Giavazzi (2006). The Economic Journal, Vol. 117, No.524, Nov. 2007. pp F634 to F642.

Cohen (2007). Review of Alesina and Giavazzi (2006). The Economic Journal, Vol. 117, No.524, Nov. 2007. pp F642 to F647.

Crafts, N. and Toniolo, G. (eds.) (1996). Economic Growth in Europe since 1945, Cambridge: Cambridge University Press.

Crafts N. (1997). 'Endogenous growth: lessons for and from economic history' in D.M. Kreps and K.F. Wallis edited Advances in economics and econometrics: theory and application (Seventh World Congress: Volume II), Econometric Society Monographs No. 27. Cambridge University Press.

Eichengreen, B. 'Institutions and Economic Growth in Europe after World War II' in Crafts, N., Toniolo, G. (1996). Economic Growth in Europe since 1945, Centre for Economic Policy Research, Cambridge.

Eichengreen, B. (2007). European Economy since 1945. Princeton University Press.

Frenkel, Jacob A.; Johnson, Harry G. (eds.). 1976. The monetary approach to the balance of payments. London, George Allen and Unwin.

Freeman, Chris. 1989. "New technology and catching up", in European Journal of Development Research (London), Vol. 1, No.1, pp. 85-99.

Freeman C. and Soete, L. 1997 The Economics of Industrial Innovation, Pinter, London.

Glyn, A.; Hughes, A.; Lipietz, ?, and Singh A. 1990. "The rise and fall of the Golden Age", in S. Marglin and J. Schor (eds.): The Golden Age of capitalism. Oxford, Clarendon Press, pp. 39-125.

Glyn, Andrew, (2006). Capitalism Unleashed, Oxford University Press, 2006 [NOT IN TEXT] 
John Hicks (1959) [To be supplied]

Kalecki, Michal. 1943. "Political aspects of full employment", in Political Quarterly (Oxford), Vol. 14, No.4 (Oct.), pp. 322-331.

Kindelberger, C.A. (1992), 'Why did the Golden Age last so long?' in F. Cairncross and A. Cairncross (eds.) The Legacy of the Golden Age, The 1960s and Their Economic Consequences. Routledge, London.

Maddison, Angus. (2001). 'The World Economy: A Millennial Perspective'. Development Centre of the Organisation for Economic Co-operation and Develoment. (OECD) Paris.

Mathews (1968) [to be supplied]

Matthews, RCO and Bowen (1988) in Eltis W. and P.Sinclair. Keynes and economic policy: The relevance of the general theory after fifty years. Macmillan, London.

OECD (2000) Historical Statistics; Paris. [To be checked]

Olson, Mancur. 1982. The Rise and Decline of Nations. New Haven, Conn.: Yale University Press.

Olson, Mancur. 1996. "The Varieties of Eurosclerosis: The Rise and Decline of Nations since 1982." In Economic Growth in Europe since 1945, ed. Nicholas Crafts and Gianni Toniolo, pp. 93-94. Cambridge: Cambridge University Press.

Phelps Edmund and Zoega Gylfi (2004). The Search for Routes to Better Economic Performance in Continental Europe. CES ifo Forum, Spring 2004, pp. 1-11.

Prescott Edward (2004). Review of Alesina and Giavazzi (2006). The Economic Journal, Vol. 117, No.524, Nov. 2007. pp F648 to F650.

Rodrik, D. (2001). The Global Governance of Trade As If Development Really Mattered, United Nations Development Programme Publications, UNDP.

Rodrik, D. and A. Subramanian (2004). Why India Can Grow At 7 Per Cent A Year or More- Projections and Reflections. Economic and Political Weekly, Special Article, 17 April 2004.

Singh, A. (1995). 'Institutional Requirements for Full Employment in Advanced Economies' International Labour Review, Vol. 134, No. 4-5.

Singh, Ajit (2007). Globalisation, Industrial Revolutions in India and China and Labour Markets in Advanced Countries: Implications for National and International Economic Policy. Working Paper No.81. International Labour Office, Geneva. 
Spero, J.E. (1977). The politics of international economic relations. London, George Allen and Unwin.

Stiglitz, Joseph (1999). "Whither Reform? Ten Years of the Transition." In Proceedings of Annual Bank Conference on Development Economics, pp. 1-32. Washington, D.C.: World Bank.

Stiglitz, Joseph (2002). Globalization and its Discontents._ Allen Lane.

World Bank (1993), East Asian Miracle. World Bank, Washington D.C. 